\title{
Application of fibrin-based hydrogels for nerve protection and regeneration after spinal cord injury
}

\author{
Ziyuan Yu, Hongru Li, Peng Xia, Weijian Kong, Yuxin Chang, Chuan Fu, Kai Wang, Xiaoyu Yang ${ }^{*}$ (D) and Zhiping Qi
}

\begin{abstract}
Traffic accidents, falls, and many other events may cause traumatic spinal cord injuries (SCls), resulting in nerve cells and extracellular matrix loss in the spinal cord, along with blood loss, inflammation, oxidative stress (OS), and others. The continuous development of neural tissue engineering has attracted increasing attention on the application of fibrin hydrogels in repairing SCls. Except for excellent biocompatibility, flexibility, and plasticity, fibrin, a component of extracellular matrix (ECM), can be equipped with cells, ECM protein, and various growth factors to promote damage repair. This review will focus on the advantages and disadvantages of fibrin hydrogels from different sources, as well as the various modifications for internal topographical guidance during the polymerization. From the perspective of further improvement of cell function before and after the delivery of stem cell, cytokine, and drug, this review will also evaluate the application of fibrin hydrogels as a carrier to the therapy of nerve repair and regeneration, to mirror the recent development tendency and challenge.
\end{abstract}

Keywords: Fibrin hydrogels, Spinal cord injury, Topographical guidance, Stem cells delivery, Cytokines delivery, Drug delivery

\section{Introduction}

The spinal cord is an integral part of the central nervous system (CNS) regulating sensory and motor function. Worldwide, 760,000 new cases of traumatic SCI occur each year as a result of traffic accidents, falls and other causes [1]. Traumatic and non-traumatic SCIs often result in limb paralysis below the injured neurological segmental level, incontinence, and sexual dysfunction [2]. Sensory function or motor function loss seriously affects the patients' life quality. The medical treatments, lifelong nursing, rehabilitation training, and other consequences put a large cost on family and society [3]. Clinical treatments of early decompressive surgery, ictus treatment of large dose methylprednisolone, exercise training, epidural stimulation, and others are to prevent the

\footnotetext{
* Correspondence: yangxiaoy@jlu.edu.cn; qizhiping1989@sina.com Department of Orthopedic Surgery, The Second Hospital of Jilin University, Ziqiang Street No. 218, Changchun, TX 130041, PR China
}

secondary death of remaining nerves or to enhance the compensation of spared circuits function [4-7]. Studies on SCIs have exhibited extreme limitation on the axon regeneration in the injured adult mammalian CNS [8]; The process of injured axons regeneration is similar to the process of axon growth during CNS development. As the size of the spinal cord increases in adulthood, axons regeneration often takes a long time to extend longer distances [9]. Besides, the surrounding inhibitory environment prevents the regenerating axon from reconnecting with the target tissue [10]. Therefore, achieving new functional connections and eliminating the inhibition from the surrounding environment have turned out a significant challenge for regenerative medicine [11].

In neural tissue engineering, multifunctional scaffolds capable of carrying cells and therapeutic molecules serve as an ideal solution to the above problems. Synthetic 
polymer scaffolds with fewer impurities and batch differences, controllable flexibility, and mechanical strength, have achieved extensive application in nerve repair [12, 13]. However, shortcomings of incomplete polymerization, harmful degradation products, and toxic residues caused by plasticizers exist in synthetic polymer scaffolds [14, 15]. Fibrin tissue sealant is a member of natural polymer and ECM, and the US Food and Drug Administration (FDA) approved it for intraoperative hemostasis and wound repair in 1998 [16]. Except for high biocompatibility, the binding sites of many cells, ECM proteins, and growth factors make fibrin hydrogels modifiable [17]. The tunable ratio of fibrinogen to thrombin can adjust fibrin hydrogel's mechanical properties to match human spinal cord tissue's mechanical properties. The elastic modulus of the human spinal cord is about $40.12 \pm 6.90 \mathrm{kPa}$, and the maximum/failure stress is about $62.26 \pm 5.02 \mathrm{kPa}$ [18]. Fibrin hydrogels can shape up in vitro or inside the spinal cord after injection. The shape of in-situ polymerized scaffolds can conform to the defect tissue to create an integrative implanttissue interface [19].

Moreover, the by-products released by fibrin hydrogels during the polymerization or in vivo degradation can facilitate the repair of damage [17]. However, the rapid degradation rate and weak mechanical properties of fibrin hydrogels make it unsuitable for application in bone tissue engineering and cartilage tissue engineering alone. Researchers usually combine fibrin hydrogels with stable and hard materials to overcome the limitations [20]. Nevertheless, fibrin has great modification potential in terms of physical and chemical properties. This report reviews the application of hydrogels composed of fibrin as the primary component in nerve repair. We have also summarized the advantages and disadvantages of various modification methods to provide a reference for better future development (Fig. 1).

\section{Physiological changes after spinal cord injury}

Pathology divides traumatic SCI into initial trauma and secondary injury. Spinal cord compression or transection caused by mechanical damage from initial trauma leads to cell death in the spinal cord and blood-spinal cord barrier dysfunction. The occurrence of a secondary injury cascade following the initial trauma is characterized by ischemia, oxidative stress, inflammatory cell infiltration, and molecule release and impaired ionic homeostasis $[2,11]$. In the acute phase of spinal cord injury, astrocytes proliferate and infiltrate in the lesion site to participate in the formation of the glial scars, the inhibitory factors expression, interstitial cell apoptosis and necrosis, excitotoxicity. Moreover, the interruption of axoplasmic transport causes the accumulation of internal calcium ions to trigger Wallerian degeneration, which

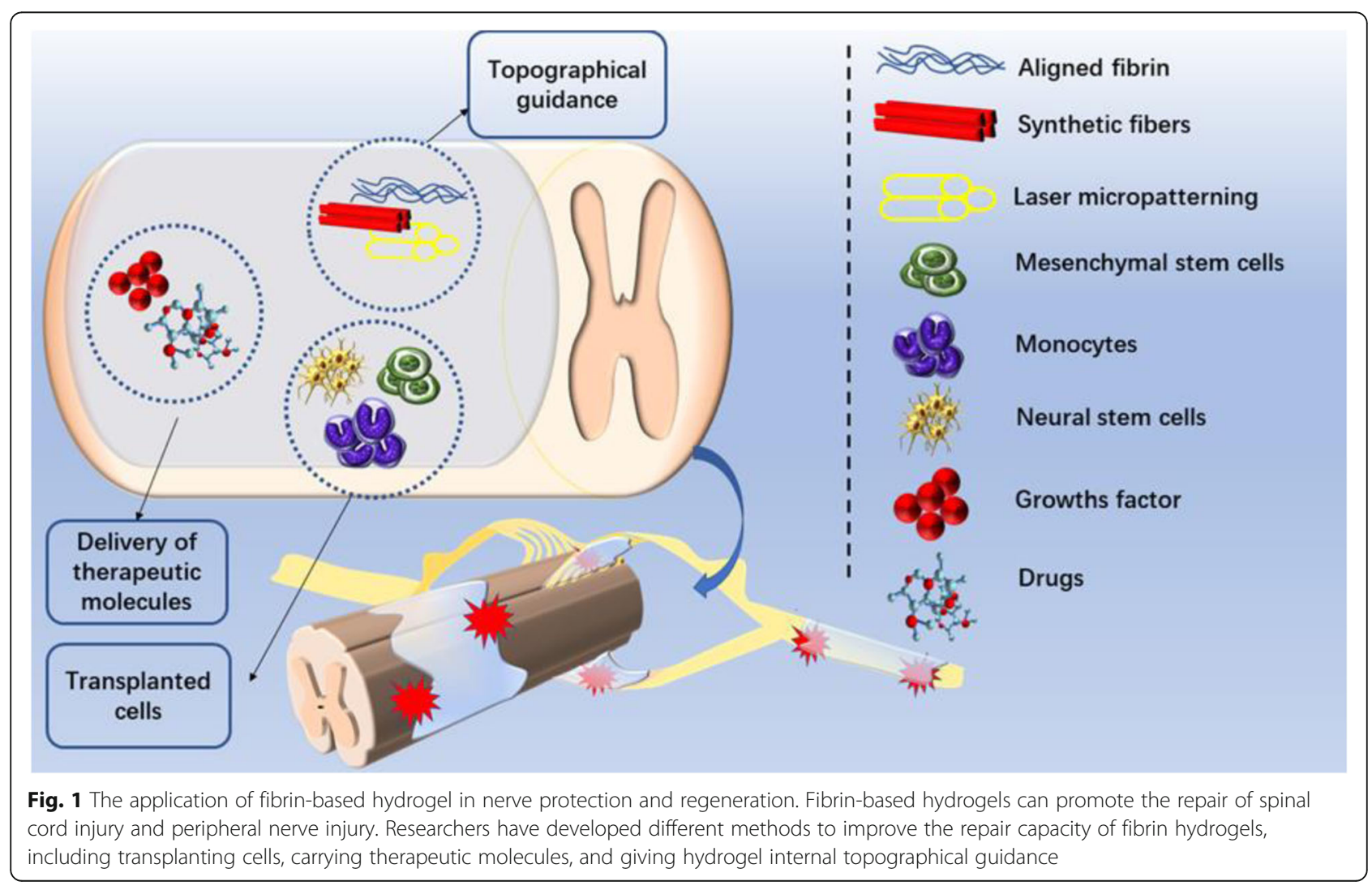


makes axon retract from the lesion site, resulting in cystic cavitation [21]. The physical inhibition of the surrounding environment caused by the glial scars, the chemical inhibition caused by chondroitin sulfate protein (CSPG), and myelin-associated inhibitors (MAIs), are identified as the primary environmental factors impeding nerve regeneration and circuit reconstruction [22, 23].

The glial scar consists of activated glial cells, meningeal cells, pericytes, and macrophages, creating a physical barrier for axon regeneration [24-26]. The glial scar is rich in CSPG, inhibiting axons and myelin sheaths growth, and oligodendroglia cell maturation [27]. Differing from the hard scars caused by other tissue injuries, spinal cord scars exhibit softer mechanical characteristics than the original tissues. Studies suggest that the soft matrix makes stem cells more likely to differentiate into glial cells rather than neurons [28]. Surgical removal of the glial scars can reduce the inhibition to some extent [29]. However, studies illustrated the protective effects of glial scars on CNS $[26,30]$. Glial scars can protect the normal nerve tissue, inhibit the inflammation damage, and facilitate the repair. Sole inhibition on glial scar formation may lead to microenvironment deterioration.

MAIs such as Nogo-A, oligodendrocyte-myelin glycoprotein, myelin-associated glycoprotein, and others are repulsive guidance cues in central nervous system maturation. MAIs can not only guide and regulate the correct migration of neurons and appropriate myelination but also stabilize the functional neuronal circuits. After SCI, the up-regulation of MAIs in neurons and oligodendrocytes at the injury site inhibits the myelination and the nerve re-innervation [31, 32].

\section{Application requirements of hydrogels in tissue engineering}

Hydrogels are cross-linked by hydrophilic polymer chains in an aqueous microenvironment, with porosity and excellent water retention [33]. The easy modification of physicochemical property, the high capacity to imitate the natural ECM, and the excellent polymerization in situ at the injury site to acquire a structure better matching the stump have moved hydrogel in favor of the application to tissue engineering $[34,35]$. Compared with the repair methods for single aplasia, the versatility of hydrogel can promote the repair of damage in many approaches. Hydrogels composed of fibrin and other natural polymers can serve as scaffolds in tissue engineering Table 1, Table 2.

However, a competent hydrogel for SCIs repair requires the following characteristics [48-53]:

(1) the mechanical properties to anastomose spinal cord tissue;
(2) the ability to combine and release peptides, proteins, and neurotrophic factors or the capacity to allow neurotrophic factors release from damaged stumps into the hydrogel;

(3) the function of filling the cavity left after SCIs and reducing the scar tissue infiltration;

(4) the promotion for the growth and differentiation of the implanted cells;

(5) the support and guidance function for new nerve tissue or transplanted cells to migrate to the lesion site;

(6) nontoxicity without incurring intense inflammations, degradability within the desired time window, and replaceability by regenerate neural tissue.

\section{The synthesis and modification of fibrin hydrogels}

Fibrinogen and thrombin are the primary materials to synthesize fibrin hydrogels. The simple preparation of fibrin hydrogels is the mixture of fibrinogen solution and thrombin solution [49], Fig. 2. Fibrinogen is a dimeric glycoprotein $45 \mathrm{~nm}$ in length and made up of three pairs of distinct chains, $A \alpha, B \beta$, and $\gamma$ chains. N-terminal of six chains concatenate in the central region, and the central region connects to the end domains on both sides by a-helical coiled coils. Fibrinopeptides A (FPA) and fibrinopeptides $\mathrm{B}$ (FPB) lie in the central region, while the $\mathrm{C}$-terminal of the $\alpha$ chains (known as the $\alpha \mathrm{C}$ domains) is near the central region. End domains on both sides contain the $C$-terminal of the $\beta$ and $\gamma$ chains [17]. After the mixture of fibrinogen and thrombin in the required ratio, FPA and FPB on the central domain region are cleaved under the action of thrombin to expose the motif Gly-Pro-Arg (GPR) on the $\alpha$-chains $\mathrm{N}$ terminal (known as knobs A) and the motif Gly-HisArg-Pro (GHRP) on the $\beta$-chains $\mathrm{N}$-terminal (known as knobs B). Knob A is complementary to holes ' $a$ ' in the C-terminal of $\gamma$ chains and knobs B is complementary to holes ' $\mathrm{b}$ ' in the $\mathrm{C}$-terminal of $\beta$ chains. In this way, the central region of one fibrinogen molecule can combine the other adjacent fibrinogen molecule end domains. Besides, the complementary binding also takes place between $\alpha \mathrm{C}$ domains of adjacent molecules [54]. Thereinto, it is believed that the A-a interaction serves as the primary driving force for the fibrin polymerization reaction, which can promote the longitudinal extension of fibrin [55]. The incomplete knowledge of the $\mathrm{B}-\mathrm{b}$ interaction function reaches an agreement that closely relates to the lateral aggregation of fibrin and the stability after polymerization [56]. The mutual binding of $\alpha \mathrm{C}$ domains of adjacent molecules is thought to promote the lateral aggregation of the protofibrils, and even the weak binding force does not play a decisive role $[57,58]$. 
Table 1 Fibrin combined with natural polymers as a scaffold in tissue engineering

\begin{tabular}{|c|c|c|c|c|c|}
\hline Composite material & $\begin{array}{l}\text { Fabrication } \\
\text { methodology }\end{array}$ & Architecture & Enhanced performance & Achievements & References \\
\hline \multirow[t]{3}{*}{ Alginate } & \multirow[t]{3}{*}{ 3D bioprinting } & \multirow{3}{*}{$\begin{array}{l}\text { Hollow gel tube-like structure, } \\
\text { the inner layer of alginate, and } \\
\text { the outer layer of fibrin }\end{array}$} & Long-term cell viability & \multirow{3}{*}{$\begin{array}{l}\text { Construction of artificial } \\
\text { arteries and veins }\end{array}$} & \multirow[t]{3}{*}{ [36] } \\
\hline & & & Biocompatibility & & \\
\hline & & & Cell adhesion & & \\
\hline \multirow[t]{4}{*}{ Chitosan } & \multirow[t]{4}{*}{ Mix } & \multirow{4}{*}{$\begin{array}{l}\text { Fibrin hydrogels embedded } \\
\text { with Sonic hedgehog (SHH)- } \\
\text { loaded chitosan }\end{array}$} & Delay the release of $\mathrm{SHH}$, & \multirow{4}{*}{$\begin{array}{l}\text { Promote spinal cord } \\
\text { regeneration }\end{array}$} & \multirow[t]{4}{*}[37]{} \\
\hline & & & Nerve regeneration & & \\
\hline & & & Recovery of motor function, & & \\
\hline & & & Reduce tissue cavities & & \\
\hline \multirow[t]{3}{*}{ Collagen } & \multirow[t]{3}{*}{$\begin{array}{l}\text { Fill conduits with } \\
\text { fibrin hydrogels }\end{array}$} & $\begin{array}{l}\text { Collagen conduits filled with } \\
\text { fibrin hydrogels }\end{array}$ & The intensity of scaffold, & \multirow{3}{*}{$\begin{array}{l}\text { Nerve conduits for } \\
\text { peripheral nerve } \\
\text { regeneration }\end{array}$} & \multirow[t]{3}{*}{ [38] } \\
\hline & & \multirow{2}{*}{$\begin{array}{l}\text { Culture autologous adipose- } \\
\text { derived mesenchymal stem } \\
\text { cells (ADMSCs) }\end{array}$} & Expression of protein GAP-43 & & \\
\hline & & & Axon regeneration & & \\
\hline \multirow[t]{2}{*}{ Fibronectin } & \multirow[t]{2}{*}{ Mix } & \multirow[t]{2}{*}{$\begin{array}{l}\text { Injectable forms of fibrin and } \\
\text { fibronectin hydrogels }\end{array}$} & $\begin{array}{l}\text { Integrate with damaged spinal } \\
\text { cord tissue, }\end{array}$ & \multirow{2}{*}{$\begin{array}{l}\text { Injectable materials to } \\
\text { fill cavities in the spinal } \\
\text { cord }\end{array}$} & \multirow[t]{2}{*}{ [39] } \\
\hline & & & Axon growth & & \\
\hline \multirow[t]{2}{*}{ Gelatin } & \multirow[t]{2}{*}{ Mix } & \multirow{2}{*}{$\begin{array}{l}\text { Bone matrix gelatin mixed fibrin } \\
\text { acts as a cell culture substrate }\end{array}$} & Biocompatibility & \multirow{2}{*}{$\begin{array}{l}\text { As a scaffold in cartilage } \\
\text { tissue engineering }\end{array}$} & \multirow[t]{2}{*}{ [40] } \\
\hline & & & $\begin{array}{l}\text { Production of collagen II and } \\
\text { aggrecan }\end{array}$ & & \\
\hline \multirow[t]{3}{*}{ Hyaluronic acid } & \multirow[t]{3}{*}{ 3D bioprinting } & \multirow{3}{*}{$\begin{array}{l}\text { Core-shell structure, Neuronal } \\
\text { cells and Schwann cells are } \\
\text { respectively located in the } \\
\text { core and shell }\end{array}$} & Neurogenesis, & \multirow{3}{*}{$\begin{array}{l}\text { Biomimetic nerve fibers } \\
\text { with a bionic tubular } \\
\text { myelin sheath }\end{array}$} & \multirow[t]{3}{*}{ [41] } \\
\hline & & & Myelin maturation, & & \\
\hline & & & $\begin{array}{l}\text { Coexistence of Schwann cells } \\
\text { and neurons }\end{array}$ & & \\
\hline \multirow[t]{2}{*}{ Albumin } & \multirow[t]{2}{*}{ Mix } & \multirow{2}{*}{$\begin{array}{l}\text { Albumin fibrin hydrogels } \\
\text { embedded in the ferromagnetic } \\
\text { fiber network }\end{array}$} & Extracellular matrix deposition & \multirow{2}{*}{$\begin{array}{l}\text { Scaffold for bone tissue } \\
\text { engineering }\end{array}$} & \multirow[t]{2}{*}{ [42] } \\
\hline & & & Vascularisation & & \\
\hline
\end{tabular}

Protofibrils finally form a branched 3D network gel structure through longitudinal extension and associate laterally.

The ratio control of fibrinogen to thrombin can regulate the thickness of the internal fibers, the porosity of the hydrogels, and the number of branch points during the polymerization of fibrin hydrogels. Thrombin catalyzes fibrinogen to release fibrinopeptides A and fibrinopeptides B. Then, it will bind to fibrin strands and maintain catalytic activity. Therefore the binding of thrombin to new strands in the network will facilitate the new polymer formation near the network [59]. At a high thrombin concentration, the distance between 'knob' and 'hole' for complementary interaction on polymers decrease, and will produce finer fibers, smaller pores, and a higher degree of connection between fibers. Reducing the concentration of thrombin during synthesis can form a porous network and increase material modulus and ultimate tensile stress [60]. Besides, the ionic strength, $\mathrm{PH}$, and other molecules present in the surrounding environment during synthesis also affect the physical the fibrin hydrogels properties. Researchers incline to the addition of molecules able to facilitate more stability and longer degradation of fibrin hydrogels, such as calcium ions, transglutaminase factor XIIIa, and anti-fibrinolytic agents including aprotinin, $\varepsilon$ aminocaproic acid, and $\alpha 2$-macroglobulin [61-68].

Apart from commercial fibrin hydrogels products [49, 69], the isolation and purification of autologous plasma can also prepare fibrin hydrogels commonly used in neural tissue engineering. However, the cost is only materials, without traffic expense and patent fee [70]. Autologous fibrin hydrogels reduce both the risk of virus transmission and concerns about non-homologous immune rejection. Besides, the cell adhesion molecules, growth factors, and cytokines in autologous fibrin can facilitate cell proliferation [71, 72]. Sharp et al. attempted to repair to hemi-cut SCI of rats by injecting hydrogel of salmon fibrin to reduce the risk of viral transmission and the occurrence rate of glial scar formation by human fibrin treatment. The result demonstrated that the rats had better motor function recovery and less abnormal pain due to the more serotonin expression at the injured end [73]. Thrombin, primarily isolated from human blood, is another critical participant in fibrin polymerization. Recently, thrombin extracted from rattlesnake venom has attracted increasing attention as an alternative to human-derived thrombin [74, 75]. 
Table 2 Fibrin combined with synthetic polymers as a scaffold in tissue engineering

\begin{tabular}{|c|c|c|c|c|c|}
\hline Composite material & Fabrication methodology & Architecture & Enhanced performance & Achievements & References \\
\hline \multirow[t]{3}{*}{$\begin{array}{l}\text { Poly (DL-lactic-co-glycolic } \\
\text { acid) (PLGA) }\end{array}$} & $\begin{array}{l}\text { Electrospray for PLGA } \\
\text { microspheres, }\end{array}$ & $\begin{array}{l}\text { Aligned fibrin hydrogels } \\
\text { loaded with PLGA } \\
\text { microspheres, }\end{array}$ & $\begin{array}{l}\text { Reduce the initial burst } \\
\text { release of drugs }\end{array}$ & \multirow[t]{3}{*}{$\begin{array}{l}\text { Promote spinal cord } \\
\text { regeneration }\end{array}$} & \multirow[t]{3}{*}{ [43] } \\
\hline & \multirow[t]{2}{*}{$\begin{array}{l}\text { Electrospinning for aligned } \\
\text { fibrin hydrogels }\end{array}$} & $\begin{array}{l}\text { PLGA microspheres } \\
\text { contain drugs }\end{array}$ & \multirow[t]{2}{*}{$\begin{array}{l}\text { Stem cells extend along } \\
\text { the long axis of the } \\
\text { aligned hydrogels }\end{array}$} & & \\
\hline & & Culture stem cells & & & \\
\hline \multirow[t]{2}{*}{ Poly(L-lactide) (PLLA) } & \multirow[t]{2}{*}{ Vacuum deposition } & \multirow{2}{*}{$\begin{array}{l}\text { Fibrin deposits on the } \\
\text { microporous walls of } \\
\text { PLLA scaffolds }\end{array}$} & $\begin{array}{l}\text { Increase elastic } \\
\text { modulus }\end{array}$ & \multirow{2}{*}{$\begin{array}{l}\text { Promote the early } \\
\text { regeneration of bone } \\
\text { and cartilage tissue }\end{array}$} & \multirow[t]{2}{*}{ [44] } \\
\hline & & & Cell adhesion & & \\
\hline \multirow[t]{3}{*}{ Polylactic Acid (PLA) } & \multirow[t]{3}{*}{ Melt-spun for PLA fibers } & $\begin{array}{l}\text { Fibrin hydrogels contain } \\
\text { square PLA fibers }\end{array}$ & Structural support & \multirow{3}{*}{$\begin{array}{l}\text { Biomaterials for } \\
\text { cardiovascular tissue } \\
\text { engineering }\end{array}$} & \multirow[t]{3}{*}[45]{} \\
\hline & & $\begin{array}{l}\text { Culture human coronary } \\
\text { artery smooth muscle cells }\end{array}$ & & & \\
\hline & & (HCASMC) & & & \\
\hline \multirow[t]{2}{*}{ Polyethylene Glycol (PEG) } & \multirow[t]{2}{*}{ Mix } & 3D Hydrogels & Neurites outgrowth & \multirow{2}{*}{$\begin{array}{l}\text { Biomaterials for } \\
\text { peripheral nerve } \\
\text { regeneration }\end{array}$} & \multirow[t]{2}{*}[46]{} \\
\hline & & $\begin{array}{l}\text { Culture dorsal root } \\
\text { ganglion (DRG) cells }\end{array}$ & $\begin{array}{l}\text { Control cells invasion } \\
\text { characteristics }\end{array}$ & & \\
\hline \multirow{2}{*}{$\begin{array}{l}\text { Polypropylene fumarate/ } \\
\text { tricalcium phosphate } \\
\text { (PPF/TCP) }\end{array}$} & $\begin{array}{l}\text { Mold method for PPF/TCP, } \\
\text { scaffolds, }\end{array}$ & Porous cylinder structure & \multirow[t]{2}{*}{ Bone growth } & \multirow[t]{2}{*}{$\begin{array}{l}\text { Biomaterials for Bone } \\
\text { tissue engineering }\end{array}$} & \multirow[t]{2}{*}[47]{} \\
\hline & $\begin{array}{l}\text { Fibrin hydrogels were } \\
\text { pipetted into the scaffolds }\end{array}$ & $\begin{array}{l}\text { Culture human gingival } \\
\text { fibroblasts (HGFs) }\end{array}$ & & & \\
\hline \multirow{5}{*}{$\begin{array}{l}\text { Multiwall carbon } \\
\text { nanotube/polyurethane } \\
\text { (MWCNT/PU) }\end{array}$} & \multirow{5}{*}{$\begin{array}{l}\text { Electrospinning for MWCNT/PU } \\
\text { fiber, fiber fragments were } \\
\text { incorporated into hydrogels }\end{array}$} & $\begin{array}{l}\text { 3D hydrogels with } \\
\text { porous structure, }\end{array}$ & Conductivity, & \multirow[t]{5}{*}{$\begin{array}{l}\text { Promote spinal cord } \\
\text { regeneration }\end{array}$} & \multirow[t]{5}{*}[48]{} \\
\hline & & \multirow{4}{*}{$\begin{array}{l}\text { Culture endometrial } \\
\text { stem cells (hEnSCs) }\end{array}$} & Hydrophilicity, & & \\
\hline & & & Hydrogels stiffness, & & \\
\hline & & & $\begin{array}{l}\text { Reduced degradation } \\
\text { rate }\end{array}$ & & \\
\hline & & & $\begin{array}{l}\text { Cell adhesion and } \\
\text { proliferation }\end{array}$ & & \\
\hline
\end{tabular}

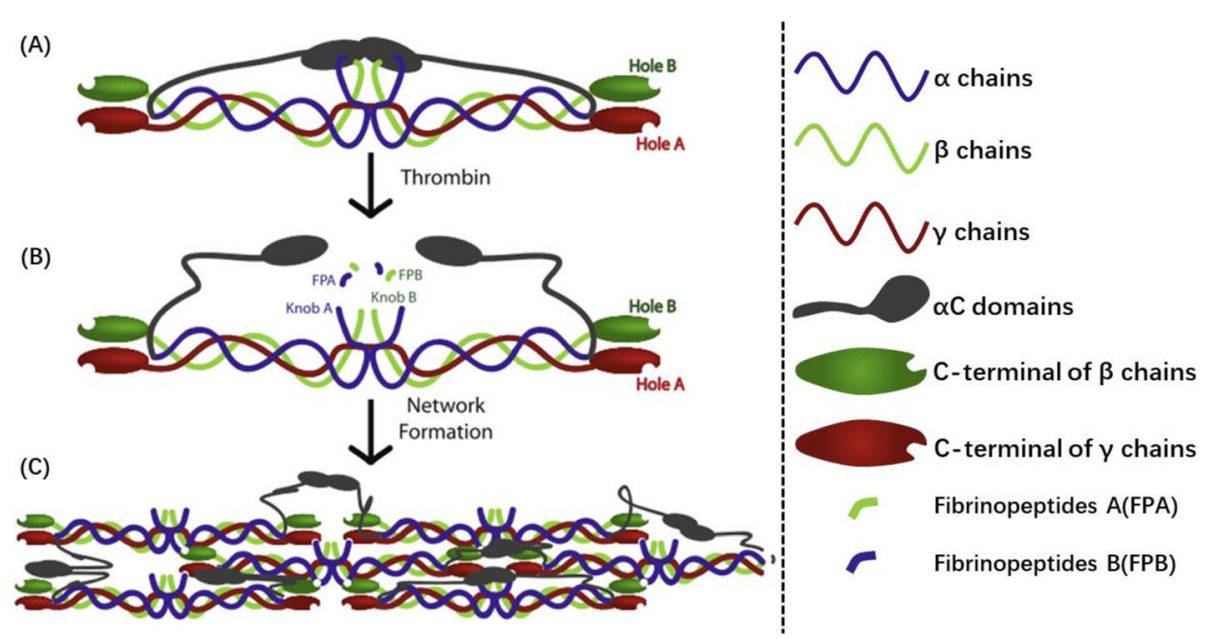

Fig. 2 Schematic diagram of fibrin polymerization. a chains are in blue, $\beta$ chains are in green, and $\gamma$ chains are in red. aC domains are in gray. a Schematic diagram of fibrinogen monomer. $\mathbf{b}$ The catalytic action of thrombin exposes knobs $\mathrm{A}$ on the a chains $\mathrm{N}$-terminal and knobs $\mathrm{B}$ on the $\beta$ chains N-terminal. c Knobs A binds to holes a, knobs B binds to holes b, and aC domains bind to aC domains on adjacent molecules, Protofibrils finally form a branched $3 \mathrm{D}$ network gel structure through longitudinal extension and associate laterally. Reprinted with permission from [17] 
Except for the similar properties to promote the repair of damage, snake venom thrombin-based fibrin hydrogels elude human-borne disease transmission due to the lack of the other human blood derivatives [76]. Spejo et al. used heterologous hydrogels synthesized by fibrinogen derived from buffalo (Bubalus bubalis) and thrombin-like protein derived from rattlesnake (Crotalus durissus terrificus) venom, which then carried mesenchymal stem cell (MSC) to repair the spinal cord ventral funiculus cut (VFC) of rats. The results discovered that the heterologous fibrin hydrogels caused up-regulation of proinflammatory cytokines at the lesion site and stimulated macrophage migration and tissue clearance; Besides, the inflammatory infiltration of the surrounding microenvironment reduced the mesenchymal stem cells' ability to promote motor function recovery [74]. When used the same fibrin hydrogels carrying human embryonic stem cell (hESC) which can overexpress human fibroblast growth factor 2 (FGF-2) to repair ventral root avulsion (VRA) injuries of the rats, the up-regulation of anti-inflammatory factor IL-10 in the ventral corn and down-regulation of mRNA level of TNFohas reflected the anti-inflammatory effect of hydrogels [75]. The interaction among the cells carried, the hydrogels and the damaged spinal cord, and the differences in growth, differentiation, and cytokine secretion of different types of stem cells ultimately lead to the different results in the inflammatory response of the receptors. The possible combination of maximum damage repair and minimum side effects reduction and the mechanism of interaction among stem cells, hydrogels, and damaged spinal cord are worthy of further research.

After polymerization, the fiber orientation inside the hydrogels is disordered. Compared with the non-aligned scaffolds, aligned scaffolds with a certain degree of internal guidance provide better terrain support to promote the arrangement and elongation of the regenerate axons [77-79]. Studies suggested that cells can perceive the topography changes of the adhesion area through the interaction of the cytoskeleton and ECM, and finally convert the physical signals' adjustment into the differentiation-related genes' expression through the transmission of focal adhesion and nuclear signals, which transform the differentiation and proliferation ability [80-83]. The fibrin hydrogels' external shape can achieve a desired structure well fits the injury site through molding and curing during the polymerization [84]. Electrospinning [85, 86] Fig. 3, 3D printing [87], cell-mediated gel contraction [88], and other techniques can prepare the aligned fibrin hydrogel with orientation inside. Yao et al. produced fibrin hydrogels by electrospinning, which endowed the fibers with a layered arrangement. The aligned hydrogel guides the human umbilical cord mesenchymal stem cells to extend in a long spindle shape. The soft elasticity of the hydrogel $(0.1-1 \mathrm{kPa})$ significantly increased the expression of neuronal differentiation markers. These two properties promote the migration and proliferation of endogenous neural cells along the fibers in the T9 hemi-cut SCI model, thereby promoting the growth of axons to the injured side [49].

Electrospinning and 3D printing technology endow fibrin hydrogels with internally aligned conduits to promote damage repair. Then surgery implants internally aligned conduits fibrin hydrogels into the damaged spinal cord. This process requires the removal of part of the vertebrae, which can easily damage the surrounding intact tissue and increase the risk of infection [89, 90]. On the other hand, spinal cord tissue defect caused by compression is usually irregular. Rigid hydrogels polymerized in vitro might not anastomose the defect tissue, which reduces the hydrogels' repairability. Injectable hydrogels can reduce unnecessary damage but lacks the internally aligned conduits [91]. Therefore, researchers developed magnetically guiding hydrogels are injectable into the spinal cord and obtain aligned fiber in situ. Based on the cascade reaction of fibrinogen and thrombin, the preparation of magnetically responsive fibrin

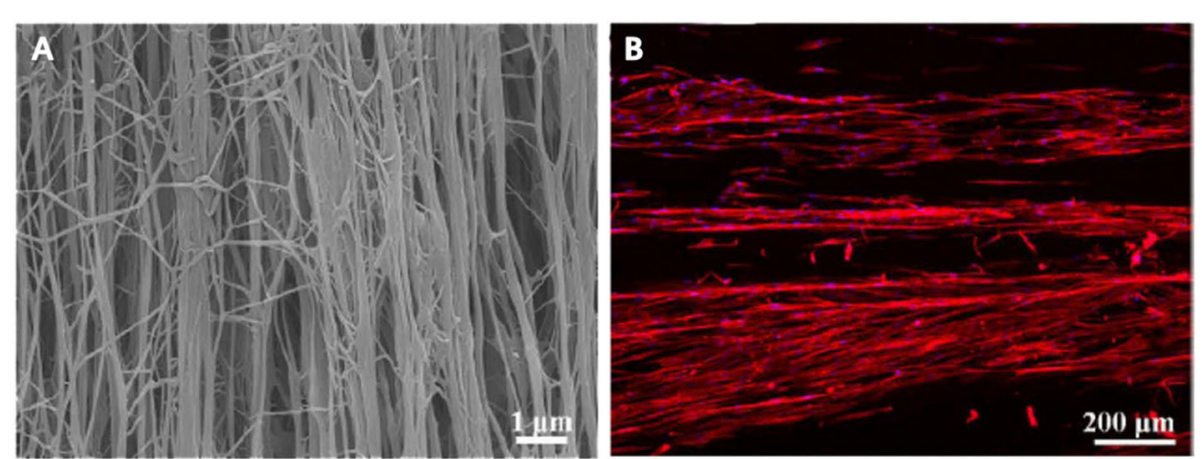

Fig. 3 a Photomicrograph of electrospinning aligned fibrin hydrogel. b Human mesenchymal stem cells (hMCS) grow along with topographical guidance in aligned fibrin hydrogel. Adapted with permission from Zhenxia Zhang [86] 
hydrogels added substances with magnetic response capabilities, such as magnetic responsive rod-shaped microgel, magnetically responsive aligned poly-L-lactic acid (PLLA), corresponding magnetic poly (lactic-co-glycolic acid) (PLGA). An external magnetic field can guide the above magnetically responsive substances to form polydisperse particle strings, which provide the topographical guidance to the interior of the hydrogels before complete solidification [92-94] Fig. 4. Besides, the side effects of synthetic substances are noteworthy. For example, the degradation of PLGA will cause an acidic environment, generating tissue toxicity, and increasing astrocytes' viability and inflammatory response [95-97]. The accumulation of reactive oxygen species (ROS) introduced by magnetic iron oxide nanoparticles that modify PLGA and PLLA will cause inflammation, damage to DNA, and the immune system [98].

The introduction of large molecular weight substances decreases the fibrin hydrogels' purity, which will change the initial setting of performance or bring the adverse effects of inorganic molecules on cells. Gessmann et al. hence, mingled plasma mixtures into the synthesis chamber which has a strong electric or magnetic field to induce fibrin alignment. The viability and proliferation of the buried human mesenchymal stem cells are impervious to the electric field's exposure during the guidance. Besides, stem cells arranged longitudinally along the direction of the aligned fibrin. During the polymerization, fibers flowing horizontally or vertically endows them with an internal directionality. The diameter of the synthetic fibrin is larger than that of the fibers synthesized in the magnetic field and electric field [99]. Berkovitch et al. employed laser photoablation to generate channels with a diameter of about $70 \pm 5 \mu \mathrm{m}$ in the hydrogel formed by ducts of synthetic polyethylene glycol and fibrinogen. The distance between the channels was $200 \mu \mathrm{m}$, which also guided the hydrogel. It promotes uniform tissue propagation during nerve regeneration [100].

\section{Fibrin hydrogels as a cell carrier}

Cell transplantation has long been supposed to be one of the most probable methods for functional recovery. MSCs, neural stem cells or progenitor cells, Schwann cells, olfactory ensheathing cells, and oligodendrocyte precursor cells are in wide application to damage repair [101]. Except for filling the damaged cavity and protecting the remnant cells [102], the implanted stem cells can differentiate into motor neurons, oligodendrocytes, astrocytes, and various ventral interneurons. The regenerate neurons will connect with the upstream and downstream neurons, regulate inflammation [103], and achieve myelination in the parenchyma surrounding the injury site [104]. The brain-derived neurotrophic factor (BDNF) and the glial cell-derived neurotrophic factor (GDNF) are expressed steadily in stem cells as the nerve growth factors that promote the regeneration of the surrounding cells and blood vessels [105, 106]. Compared with the surrounding environment, the concentration gradient of growth factors also poses a guiding effect on the regeneration of autologous axons to some extent [107].

\section{Fibrin hydrogels carrying mesenchymal stem cells}

MSCs involved in the repair of damage has proved the potential to differentiate into neurons and glial cells. The cytokines and neurotrophic factors expressed during the differentiation, the immune regulation, and the antiapoptosis can help improve the motor function [108110]. Compared with the plastic surface, the Arg-Gly-Asp
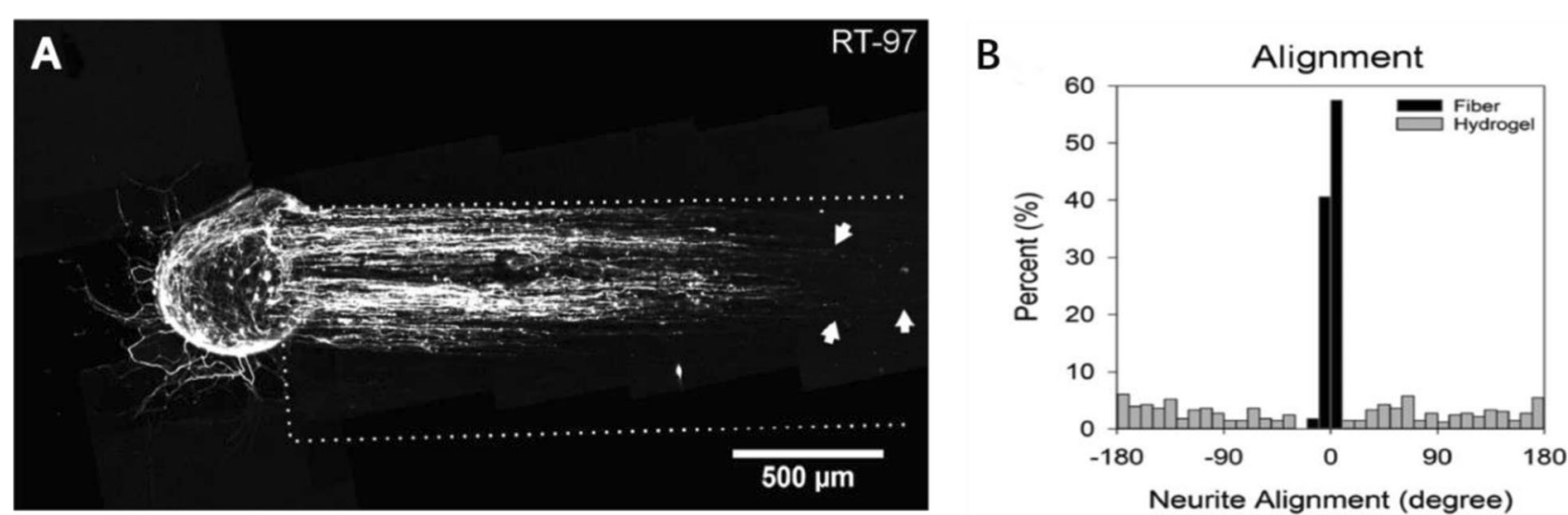

Fig. 4 a Dorsal root ganglion cells were cultured in fibrin hydrogels containing 6\% superparamagnetic iron oxide nanoparticles (SPIONs) and PLLA fibers. Dorsal root ganglion cells were labeled with RT-97 for neurofilament, white dotted lines Indicates the area with nerve fibers, and the white arrow indicates the three longest neurites. $\mathbf{b}$ Histograms showing the distribution of neurite growth angles $\left( \pm 180^{\circ}\right)$, Each bar represents a $10^{\circ}$ bin (\% of total) 
(RGD) sequence and the larger surface endow MSCs with a higher proliferation rate and promote the differentiation to Schwann-like cells (SLCs) [111]. MSCs can function in the repair of SCIs of different types or at different phases. Mukhamedshina et al. added adipose-derived mesenchymal stem cells (ADMSCs) to wrap the rat spinal cord with 2 weeks of compression injury. The result after adding MSCs found that the down-regulation expression of the glial fibrillary acidic protein (GFAP) and the allograft inflammatory factor 1 (IBA1) suggested a decrease in astrocyte activation. Besides, the up-regulation expression of the platelet-derived growth factor $\beta$-receptor (PDGF $\beta R$ ) and the heat shock $70 \mathrm{kDa}$ protein 1B (HSPA1b) (antiapoptotic regulator) mRNA, prevented the secondary damage and promoted the retention of gray and white matter [102]. Compared with compression injury, spinal cord transection injury can eliminate the well-functioning nerves' interference in therapeutic effect evaluation [112]. After the microinjection of the mixture of fibrin hydrogels and ovine bone marrow mesenchymal stem cells into the rats with spinal cord transection injury, MSCs can migrate into the spinal cord of the host and begin to differentiate into neurons and glial cells, which promote the recovery of partial motor function [113]. In the chronic phase of spinal cord transverse injury, the surgical removal of scar tissue and the addition of scar inhibitors can facilitate the fibrin hydrogel scaffolds carrying MSCs to create a microenvironment more suitable for axon regeneration, and also promote the further functional recovery of electrophysiology and motion [114]. A contrastive repair competence of various MSCs applicable for SCI transplantation suggests that adipose tissue MSCs (AD-MSCs) demonstrated the best repair effect in the motor ability recovery, inhibiting the activation of microglia and astroglia in caudal direction of injury epicenter, reducing the cavitation after trauma, and enhancing the tissue restoration. The allogeneic MSCs carried by fibrin hydrogels in the comparison conducted by implanting into SCI models are bone marrow MSCs (BM-MSCs), AD-MSCs, and dental pulp (DP-MSCs) [115].

\section{Fibrin hydrogels carrying neural stem/ progenitor cells}

Neural stem/ progenitor cells are other cells widely used in the repair of damage. Except for the ability to reduce the formation of glial scar and reduce inflammation effectively Neural stem/ progenitor cells have a stronger neuronal differentiation tendency [116]. Likewise, fibrin hydrogels can provide embryonic stem cell-derived neural stem/progenitor cells (ES-NSPs) [117], neural progenitor cells (NPC) [118], human embryonic stem cells (hESC) [75], embryonic stem cell-derived motor neuron progenitor cells [119], and other cells, a suitable environment for proliferation and differentiation. Also, the implantation to fill the damaged site can not only reduce the cavitation after the trauma but also promote the axon extension and the motor function recovery. The flexibility of fibrin hydrogels can induce neural stem/progenitor cells (NSPC) to differentiate into dopaminergic/noradrenergic neurons and synaptic protein networks [120]. Monfared et al. acquired oligodendrocyte progenitor cells (OPC) by inducing human endometrial stem cells (hEnSCs) to overexpress miR-219, which were wrapped in fibrin hydrogels and injected into the rat spinal cord compression injury site. The results demonstrated that the OPC group achieved a higher myelination rate than the hEnSC group from where it originated. However, no significant difference appeared in the hindlimb motor function recovery between the two groups, which illustrated that myelination might not be the critical reason for motor function recovery to some extent [121].

\section{Fibrin hydrogels carrying other cells}

Schwann cells, considered as the gold standard cell type for the treatment of peripheral injury at present, can proliferate again to longitudinally oriented bands of $\mathrm{Bu}$ "ngner after damage, to support the axon orientation growth [122] and provide bioactive substances for axon migration and growth $[123,124]$. Both in vitro culture and in vivo repair of sciatic nerves improved Schwann cells' viability and supported aligned nerve tissue formation, increasing the number of neurites in the graft and distal stumps [118, 125]. However, the short survival time of the Schwann cells and the inconspicuous axon regeneration and functional recovery remain after the Schwann cells' implantation to the spinal cord [126, 127]. Ganz et al. implanted human oral mucosal stem cells (hOMSC) into the matrix consist of fibrin, PLLA, and PLGA to repair the complete spinal cord transection injury. The implanted cells released GDNF, BDNF, and neurotrophin-3 (NT-3), in which the increased myelinated axons and neural precursors reduced the formation of glial scars [128]. The mixture of progenitor cells contained in monocytes in human peripheral blood exhibits the potential to differentiate into neural stem cells [129]. Barbizan et al. applied the fibrin hydrogels coated with monocytes through local injection to repair the ventral root-lesion of the spinal cord. The implantation increased the neurotrophic factors' expression in the spinal cord's ventral horn and promoted the motor function recovery [130, 131]. The same application to the dorsal root lesion also reduced glial accumulation and improved the sensory input axon plasticity [132].

\section{Further functional optimization on the hydrogels and the cells}

The surrounding environment' inhibition to the implanted stem cells' proliferation and the incorrect stem 
cells' proliferation will reduce the repair effect [133, 134]. Further optimization on the stem cells, the increase of the cell's proliferation and population purity, and the culture of cell populations more propitious to nerve repair are of necessity [135]. The achievements need Further functional modification of the hydrogels and the cells.

\section{Optimization on fibrin hydrogels' function}

Researchers have further processed the properties of the hydrogel matrix to achieve the requirement more suitable for cell growth. For example, fiber fragments produced by the filler of electrospun polyurethane/multiwall carbon nanotube in the synthesis of fibrin hydrogels can improve fibrin hydrogels' rigidity and prolong their degradation, which makes them more suitable for spinal transplantation and improve the vitality and proliferation of the cells carried [48]. The addition of perfluorotributylamine (PFTBA) during the polymerization can facilitate the remyelination and the motor function recovery. Because the high solubility for oxygen of PFTBA can release continuous oxygen, which is conducive to the cells' survival and the growth of the microvessels in the early regeneration of the nerve [136]. Except for the application of inorganic molecules, the introduction of other proteins can also enrich the function of fibrin hydrogels. Arulmoli et al. added hyaluronic acid (HA) and laminin into the polymerization of the salmon-derived fibrin hydrogels. The result demonstrated that except for the increased rigidity and the prolonged degradation, the integrin-binding site provided by laminin could mediate the interaction between cells and hydrogel. Besides, the above fibrin hydrogels enhanced the human endothelial colony-forming cell-derived endothelial cells (hECFCECs)-mediated angiogenesis and supported the proliferation and differentiation of the human neural stem/progenitor cells (hNSPCs) [137]. Studies suggest that the binding of integrin to extracellular matrix ligands is essential for cells anchorage to the surrounding matrix, migration, and activation of intracellular signaling pathways. Researchers used the enzyme cross-linking of transglutaminase factor XIII to covalently bind synthetic peptide (HYD1) to fibrin hydrogels. Synthetic peptides can serve as ligands for integrin a6b1 expressed by neural stem/progenitor cells (NSPCs), Therefore, functionalized fibrin hydrogels can promote the neurite extension of cultured NSPCs and improve the motor function of SCI rats after implantation [117]. Fibrin hydrogels can not only carry the cells but also serve as an additive to the extracellular matrix hydrogel of bone or spinal cord, making the gelation rate and storage modulus of the mixed hydrogel more suitable for the transplantation into the spinal cord [138].

\section{Optimization on the carried cells' function}

The filler of the various cytokines into the hydrogels carrying cells can endow the cells with the potential to differentiate more exclusively and endow the hydrogels with the potential to create an ideal microenvironment. Edgar et al. added retinoic acid and purmorphamine into the hydrogels carrying human induced pluripotent stem cells. The results exhibited that the addition promoted the carried cells' differentiation to the spinal motor neurons, which reduced the astrocyte progenitor genes' expression and made the neuronal population purer [139]. In the presence of basic fibroblast growth factor (bFGF), corning ${ }^{\text {ma }}$ epidermal growth factor (EGF), and platelet-derived growth factor AA (PDGF-AA), fibrin hydrogels can improve cell viability and promote pluripotent stem cells' (iPSC) differentiation into oligodendrocytes [140]. The combined application of BDNF, bFGF, cell death inhibitor (MDL28170), and vascular endothelial (VEGF) improves the transplanted cells' survival rate, which will facilitate a wide range of stem cell-derived axonal outgrowth in the lesion [118]. In addition to the exogenous cytokines, fibrin is also a carrier for cells modified for the overexpression of basic fibroblast growth factor (FGF2). Human intervention can precisely regulate the timing of the transfected cells releasing the cytokine, which facilitates the evaluation of the efficacy of tissue cell engineering in different nerve injury phases [75].

However, some experiments suggest that fibrin carrying both cells and drugs can not always achieve superimposed advantages. Wilems et al. transplanted fibroin hydrogel-coated embryonic stem cell-derived motor neuron progenitor cells and anti-inhibitory microparticle systems (equipped with Chondroitinase $A B C$ and nogo extracellular peptide, residues 1-40) into rat subacute SCI models. The combined application resulted in inflammation aggravation, macrophages cell infiltration, and chondroitin sulfate proteoglycans (CSPGs) increase at the transplant site, which reduced the transplanted cells' survival rate [119]. In the experiment of Pajer et al., after implanting the human fibrin hydrogels carrying stem cells (NE-GFP-4C cell line), the disintegrated fibrin matrix induced stem cells' death, which failed to improve the motor function and reduce the formation of glial [141]. Besides, the undesirable consequences of cell transplantation are noteworthy, such as allodynia caused by abnormal astrocyte differentiation [142], pain and spasm caused by the inappropriate functional connection of regenerative axons [143], tumors caused by excessive hyperplasia [133], abnormal activities and tissue compression caused by ectopic colonies [144], and others. Moreover, the optimal scaffold and cell combination and appropriate regulation route are worth further research. 


\section{Fibrin hydrogels carrying therapeutic molecules and drug}

Fibrin comprises many integrin peptide-binding sequences able to combine with various cells. The binding sites of fibrin to ECM protein and various growth factors enrich the means of its involvement in nerve repair [17], making fibrin hydrogels an excellent carrier candidate.

\section{Fibrin hydrogels carrying therapeutic molecules and drug} Fibrin hydrogels reversibly bind to various cytokines that promote the repair of SCIs, such as fibroblast growth factor (FGF), vascular endothelial growth factor (VEGF), neurotrophin-3(NT-3), and platelet-derived growth factor (PDGF) [54, 145]. The safety and feasibility of acidic fibroblast growth factor (aFGF) for the repair of chronic SCI have received extensive affirmation [146]. Fibrin hydrogels and aFGF co-injected in patients with spinal cord injury can prevent postoperative cerebrospinal fluid leakage and promote motor function recovery [147]. Hydrogels carrying fibroblast growth factor- 1 can create a more permissive environment for M2 macrophages to participate in the repair of injury [148]. VEGF can be continuously released in fibrin hydrogels and promote the aggregation and differentiation of neural stem cells [149]. The T1 sequence from angiogenic inducer cellular communication network factor 1 (CCN1) covalently combined with factor XIIIa can participate in fibrin hydrogels synthesis. Furthermore, the fibrin hydrogels, after modification, illustrated a higher angiogenic function under the mediation of vascular endothelial growth factor (VEGF) [150]. The hydrogels carrying erythropoietin (EPO) can promote nerve regeneration and motor recovery in the repair of the early phase of compression injury [151]. Fibrin hydrogels also can be used as a carrier for antisense oligonucleotides (AONs), which mediates effective gene silencing by direct blocking or degrading target transcripts. Locally applied AONs effectively down-regulates the expression of glycogen synthase kinase 3 beta (GSK3 $\beta$ ) in the injured segment, and the down-regulation of GSK3 $\beta$ enhances the intrinsic axon regeneration potential [152].

\section{Regulate the release rate of therapeutic molecules and drugs}

The mixture of cytokines and drugs will face uncontrolled burst release from the polymer, which will cause high dose toxicity and drug release, reducing therapeutic effect [153]. Taylor et al. constructed a heparin-based NT-3 delivery system. Linker peptide binds to the fibrin hydrogels through covalent cross-linking and serves to sequester heparin in the fibrin hydrogels. At the same time, heparin binds NT-3 through electrostatic action, and the concentration of heparin modulates the release rate of NT-3. Fibrin hydrogels containing NT-3 increase neural fibers density in the injured spinal cord [154]. Direct addition to the fibrin hydrogels will cause the rapid degradation of chondroitinase $\mathrm{ABC}$ (ChABC) [155] However, after being carried by Lipid microtubes, $\mathrm{ChABC}$ can achieve a slow and stable release, promoting the neurites' extension [156]. The drug delivery system for SCI's clinical treatment has witnessed a similar means, increasing the drug targeting ability while reducing the systemic toxicity. The clinical effectiveness and stability of methylprednisolone sodium succinate (MPSS) promptly within $8 \mathrm{~h}$ after SCIs are crucial [157]. Polycaprolactone-based nanoparticles carrying MPSS are dispersing in fibrin hydrogels. After the implantation into acute SCI rats, the fibrin and nanoparticles protect MPSS from rapid hydrolysis, which maintains an 8 h' therapeutic dose in the lesion site. Local application exhibited a higher targeting ability and could reduce the spinal cord injury at the level of caspase-3, which demonstrated a similar therapeutic effect to systemic highdose methylprednisolone [158]. Immunosuppressant tacrolimus (FK506) coated with solubilized and granular partial PLGA microspheres in fibrin hydrogels can achieve a controlled release for 28 days. FK506 microspheres can facilitate more motor, and sensory neurons regenerate in rats and produce more myelinated axons at the distal end of the injury. Compared with the systemic application, no detection of FK506 is in other essential organs, except for the nerve site, avoiding systemic toxicity [159].

\section{Conclusions}

Since its introduction, fibrin hydrogel, as one of the most promising natural polymers in neural tissue engineering, has witnessed the development and a broad application in neural tissue engineering, bone tissue engineering, skin tissue engineering, and other fields. Despite the advantages mentioned above, fibrin-based hydrogels still face many challenges. Despite the advantages of biocompatibility, modifiability, and the ability to carry multiple cells and therapeutic factors, challenges continue in the clinical application of fibrin-based hydrogels. The FDA has approved many materials for peripheral nerve injuries repair [160]. A functional scaffold shall meet the clinical requirements of biocompatibility and interaction with cell tissue except for access to the specific physical, chemical, mechanical, and degradation properties. Besides, ethics, government regulation, development cost, clinician preference, and others are the issues involved [161]. Researchers tend to evaluate the repair effect by implanting hydrogel scaffold into animal models of spinal cord transection or hemisection. The animal models' tissue defects are regular, different from the irregular ones of human traumatic SCIs, usually with vertebrae, intervertebral discs, and ligament 
injuries. Irregular tissue defects may generate inaccurate implantation of scaffold and inconsonant therapeutic effects on different levels of damage [162]. Injectable fibrin hydrogel can polymerize in vivo to anastomose the irregular defects but fails to provide topographical guidance to cells. Magnetic response injectable hydrogels can solve the preceding problem by magnetically positioning in situ, and providing consistent topographical guidance. The use of heterologous hydrogels can reduce the risk of blood-borne diseases, but the retention of heterologous substances in the body can also trigger a specific inflammatory response. When fibrin hydrogels carry cells, cytokines, or drugs in the repair of SCIs, the therapeutic effect depends on the function of the carried substances. The structure and intrinsic potential of hydrogel still need further modification and improvement, the interaction of hydrogels with cells and therapeutic agents warrants further investigation. Briefly, the support of increasing cross-linking and modification technologies will unlock more potentials of fibrin hydrogels in neural tissue engineering.

\section{Abbreviations}

SCls: Spinal cord injuries; ECM: Extracellular matrix; CNS: Central nervous system; FDA: Food and Drug Administration; CSPG: Chondroitin sulfate protein; MAls: Myelin-associated inhibitors; FPA: Fibrinopeptides A; FPB: Fibrinopeptides B; MSC: Mesenchymal stem cell; hESC: Human embryonic stem cell; FGF: Human fibroblast growth factor; PLLA: Poly-L-lactic acid; PLGA: Poly (lactic-co-glycolic acid); BDNF: Brain-derived neurotrophic factor; GDNF: Glial cell-derived neurotrophic factor; ADMSCs: Adipose-derived mesenchymal stem cells; NSPC: Neural stem/progenitor cell; OPC: Oligodendrocyte progenitor cells; hENSCs: Human endometrial stem cells; NT-3: Neurotrophin-3; PFTBA: Perfluorotributylamine; VEGF: Vascular endothelial; ChABC: Chondroitinase ABC; MPSS: Methylprednisolone sodium succinate

\section{Acknowledgments}

Not applicable.

\section{Authors' contributions}

All authors helped in drafting the manuscript. All authors read and approved the final manuscript.

\section{Funding}

Not applicable.

\section{Availability of data and materials}

Not applicable.

\section{Ethics approval and consent to participate}

Not applicable.

\section{Consent for publication}

Not applicable.

\section{Competing interests}

The authors declare that they have no competing interests.

Received: 27 May 2020 Accepted: 27 July 2020

Published online: 03 August 2020

\section{References}

1. Kumar R, Lim J, Mekary RA, Rattani A, Dewan MC, Sharif SY, et al. Traumatic spinal injury: global epidemiology and worldwide volume. World Neurosurg. 2018;113:E345-E63.
2. Ahuja CS, Wilson JR, Nori S, Kotter MRN, Druschel C, Curt A, et al. Traumatic spinal cord injury. Nat Rev Dis Primers. 2017;3.

3. Dukes EM, Kirshblum S, Aimetti AA, Qin SS, Bornheimer RK, Oster G. Relationship of American spinal injury association impairment scale grade to post-injury hospitalization and costs in thoracic spinal cord injury. Neurosurgery. 2018;83(3):445-51.

4. Ulndreaj A, Badner A, Fehlings MG. Promising neuroprotective strategies for traumatic spinal cord injury with a focus on the differential effects among anatomical levels of injury. F1000Res. 2017;6:1907.

5. Evaniew N, Belley-Cote EP, Fallah N, Noonan VK, Rivers CS, Dvorak MF. Methylprednisolone for the treatment of patients with acute spinal cord injuries: a systematic review and meta-analysis. J Neurotrauma. 2016;33(5): 468-81.

6. Angeli CA, Boakye M, Morton RA, Vogt J, Benton K, Chen Y, et al. Recovery of over-ground walking after chronic motor complete spinal cord injury. N Engl J Med. 2018;379(13):1244-50.

7. Miller LE, Zimmermann AK, Herbert WG. Clinical effectiveness and safety of powered exoskeleton-assisted walking in patients with spinal cord injury: systematic review with meta-analysis. Med Devices-Evid Res. 2016;9.

8. Ribas VT, Costa MR. Gene manipulation strategies to identify molecular regulators of axon regeneration in the central nervous system. Front Cell Neurosci. 2017;11.

9. He Z, Jin Y. Intrinsic control of axon regeneration. Neuron. 2016;90(3):437-51.

10. Neumann B, Linton C, Giordano-Santini R, Hilliard MA. Axonal fusion: an alternative and efficient mechanism of nerve repair. Prog Neurobiol. 2019; 173:88-101.

11. Ahuja CS, Nori S, Tetreault L, Wilson J, Kwon B, Harrop J, et al. Traumatic spinal cord injury-repair and regeneration. Neurosurgery. 2017;80(3):S9-S22.

12. Boni R, Ali A, Shavandi A, Clarkson AN. Current and novel polymeric biomaterials for neural tissue engineering. J Biomed Sci. 2018;25(1):90.

13. Amani $\mathrm{H}$, Kazerooni $\mathrm{H}$, Hassanpoor $\mathrm{H}$, Akbarzadeh A, Pazoki-Toroudi $\mathrm{H}$. Tailoring synthetic polymeric biomaterials towards nerve tissue engineering: a review. Artif Cells Nanomed Biotechnol. 2019;47(1):3524-39.

14. Washington MA, Balmert SC, Fedorchak MV, Little SR, Watkins SC, Meyer TY. Monomer sequence in PLGA microparticles: effects on acidic microclimates and in vivo inflammatory response. Acta Biomater. 2018;65:259-71.

15. Hoess A, Lopez A, Engqvist H, Ott MK, Persson C. Comparison of a quasidynamic and a static extraction method for the cytotoxic evaluation of acrylic bone cements. Mater Sci Eng C-Mater Biol Appl. 2016;62:274-82.

16. Spotnitz WD. Fibrin sealant: past, present, and future: a brief review. World J Surg. 2010;34(4):632-4.

17. Brown AC, Barker TH. Fibrin-based biomaterials: modulation of macroscopic properties through rational design at the molecular level. Acta Biomater. 2014;10(4):1502-14.

18. Karimi A, Shojaei A, Tehrani P. Mechanical properties of the human spinal cord under the compressive loading. J Chem Neuroanat. 2017;86:15-8.

19. Macaya $D$, Spector M. Injectable hydrogel materials for spinal cord regeneration: a review. Biomed Mater. 2012;7(1).

20. Noori A, Ashrafi SJ, Vaez-Ghaemi R, Hatamian-Zaremi A, Webster TJ. A review of fibrin and fibrin composites for bone tissue engineering. Int J Nanomedicine. 2017;12:4937-61.

21. Coleman M. Axon degeneration mechanisms: commonality amid diversity. Nat Rev Neurosci. 2005;6(11):889-98.

22. Rishal I, Fainzilber M. Axon-soma communication in neuronal injury. Nat Rev Neurosci. 2014;15(1):32-42.

23. Horn KP, Busch SA, Hawthorne AL, van Rooijen N, Silver J. Another barrier to regeneration in the CNS: activated macrophages induce extensive retraction of dystrophic axons through direct physical interactions. J Neurosci. 2008; 28(38):9330-41.

24. Goritz C, Dias DO, Tomilin N, Barbacid M, Shupliakov O, Frisen J. A Pericyte origin of spinal cord scar tissue. Science. 2011;333(6039):238-42.

25. Soderblom C, Luo X, Blumenthal E, Bray E, Lyapichev K, Ramos J, et al. Perivascular Fibroblasts Form the Fibrotic Scar after Contusive Spinal Cord Injury. J Neurosci. 2013;33(34):13882.

26. Adams KL, Gallo V. The diversity and disparity of the glial scar. Nat Neurosci. 2018;21(1):9-15.

27. Amanda Phuong T, Warren PM, Silver J. The biology of regeneration failure and success after spinal cord injury. Physiol Rev. 2018;98(2):881-917.

28. Moeendarbary E, Weber IP, Sheridan GK, Koser DE, Soleman S, Haenzi B, et al. The soft mechanical signature of glial scars in the central nervous system. Nat Commun. 2017;8:14787. 
29. Li X, Yang B, Xiao Z, Zhao Y, Han S, Yin Y, et al. Comparison of subacute and chronic scar tissues after complete spinal cord transection. Exp Neurol. 2018;306:132-7

30. Rasouli A, Bhatia N, Dinh P, Cahill K, Suryadevara S, Gupta R. Resection of glial scar following spinal cord injury. J Orthop Res. 2009;27(7):931-6.

31. Lee JK, Zheng B. Role of myelin-associated inhibitors in axonal repair after spinal cord injury. Exp Neurol. 2012;235(1):33-42.

32. Boghdadi AG, Teo L, Bourne JA. The involvement of the myelin-associated inhibitors and their receptors in CNS plasticity and injury. Mol Neurobiol. 2018;55(3):1831-46.

33. Zhang YS, Khademhosseini A. Advances in engineering hydrogels. Science. 2017:356(6337).

34. Guan X, Avci-Adali M, Alarcin E, Cheng H, Kashaf SS, Li Y, et al. Development of hydrogels for regenerative engineering. Biotechnol J. 2017;12(5).

35. Zhao Y-Z, Jiang X, Xiao J, Lin Q, Yu W-Z, Tian F-R, et al. Using NGF heparinpoloxamer thermosensitive hydrogels to enhance the nerve regeneration for spinal cord injury. Acta Biomater. 2016;29:71-80.

36. Attalla R, Puersten E, Jain N, Selvaganapathy PR. 3D bioprinting of heterogeneous bi- and tri-layered hollow channels within gel scaffolds using scalable multi-axial microfluidic extrusion nozzle. Biofabrication. 2019;11(1).

37. Yang WJ, Wang Z, Zhang JX, Yang KY, Lu C, Cui XW, et al. Fibrin scaffolds embedded with sonic hedgehog/chitosan microspheres for recovery of spinal cord injury in rats. Mater Express. 2020;10(3):437-45.

38. Carriel V, Garzon I, Campos A, Cornelissen M, Alaminos M. Differential expression of GAP-43 and neurofilament during peripheral nerve regeneration through bioartificial conduits. J Tissue Eng Regen Med. 2017; 11(2):553-63.

39. King VR, Alovskaya A, Wei DYT, Brown RA, Priestley JV. The use of injectable forms of fibrin and fibronectin to support axonal ingrowth after spinal cord injury. Biomaterials. 2010;31(15):4447-56.

40. Wang ZH, Zhang J, Zhang Q, Gao Y, Yan J, Zhao XY, et al. Evaluation of bone matrix gelatin/fibrin glue and chitosan/gelatin composite scaffolds for cartilage tissue engineering. Genetics and Molecular Research. 2016;15(3).

41. Chen SP, Wu CH, Liu A, Wei D, Xiao Y, Guo ZZ, et al. Biofabrication of nerve fibers with mimetic myelin sheath-like structure and aligned fibrous niche. Biofabrication. 2020;12(3)

42. Levy GK, Ong J, Birch MA, Justin AW, Markaki AE. Albumin-Enriched Fibrin Hydrogel Embedded in Active Ferromagnetic Networks Improves Osteoblast Differentiation and Vascular Self-Organisation. Polymers. 2019;11(11).

43. Yao SL, Yang YD, Wang XM, Wang LN. Fabrication and characterization of aligned fibrin nanofiber hydrogel loaded with PLGA microspheres. Macromol Res. 2017;25(6):528-33.

44. Gamboa-Martinez TC, Ribelles JLG, Ferrer GG. Fibrin coating on poly (Llactide) scaffolds for tissue engineering. J Bioact Compat Polym. 2011;26(5): 464-77.

45. Gundy S, Manning G, O'Connell E, Ella V, Harwoko MS, Rochev Y, et al. Human coronary artery smooth muscle cell response to a novel PLA textile/ fibrin gel composite scaffold. Acta Biomater. 2008;4(6):1734-44.

46. Sarig-Nadir O, Seliktar D. Compositional alterations of fibrin-based materials for regulating in vitro neural outgrowth. Tissue Eng A. 2008;14(3):401-11.

47. Schek RM, Wilke EN, Hollister SJ, Krebsbach PH. Combined use of designed scaffolds and adenoviral gene therapy for skeletal tissue engineering. Biomaterials. 2006;27(7):1160-6.

48. Hasanzadeh E, Ebrahimi-Barough S, Mirzaei E, Azami M, Tavangar SM, Mahmoodi N, et al. Preparation of fibrin gel scaffolds containing MWCNT/ PU nanofibers for neural tissue engineering. J Biomed Mater Res A. 2019; 107(4):802-14

49. Yao S, Liu X, Yu S, Wang X, Zhang S, Wu Q, et al. Co-effects of matrix low elasticity and aligned topography on stem cell neurogenic differentiation and rapid neurite outgrowth. Nanoscale. 2016;8(19):10252-65.

50. Mehrali M, Thakur A, Pennisi CP, Talebian S, Arpanaei A, Nikkhah M, et al. Nanoreinforced Hydrogels for Tissue Engineering: Biomaterials that are Compatible with Load-Bearing and Electroactive Tissues. Adv Mater. 2017;29(8).

51. Anderson MA, Burda JE, Ren $Y$, Ao $Y$, O'Shea TM, Kawaguchi $R$, et al. Astrocyte scar formation aids central nervous system axon regeneration. Nature. 2016;532(7598):195

52. Sun Y, Li W, Wu X, Zhang N, Zhang Y, Ouyang S, et al. Functional selfassembling peptide Nanofiber hydrogels designed for nerve degeneration. ACS Appl Mater Interfaces. 2016;8(3):2348-59.
53. Caron I, Rossi F, Papa S, Aloe R, Sculco M, Mauri E, et al. A new three dimensional biomimetic hydrogel to deliver factors secreted by human mesenchymal stem cells in spinal cord injury. Biomaterials. 2016;75:135-47.

54. Janmey PA, Winer JP, Weisel JW. Fibrin gels and their clinical and bioengineering applications. J R Soc Interface. 2009:6(30):1-10.

55. Litvinov Rl, Gorkun OV, Owen SF, Shuman H, Weisel JW. Polymerization of fibrin: specificity, strength, and stability of knob-hole interactions studied at the single-molecule level. Blood. 2005;106(9):2944-51.

56. Weisel JW, Litvinov RI. Fibrin formation, Structure and Properties. Sub-Cell Biochem. 2017;82:405-56.

57. Duval C, Profumo A, Aprile A, Salis A, Millo E, Damonte G, et al. Fibrinogen alpha C-regions are not directly involved in fibrin polymerization as evidenced by a "double-Detroit" recombinant fibrinogen mutant and knobs-mimic peptides. J Thromb Haemost. 2020;18(4):802-14

58. Veklich Yl, Gorkun OV, Medved LV, Nieuwenhuizen W, Weisel JW. Carboxylterminal portions of the alpha chains of fibrinogen and fibrin. Localization by electron microscopy and the effects of isolated alpha $C$ fragments on polymerization. J Biol Chem. 1993;268(18):13577-85.

59. Blomback B, Bark N. Fibrinopeptides and fibnin gel structure. Biophys Chem. 2004;112(2-3):147-51.

60. Rowe SL, Lee S, Stegemann JP. Influence of thrombin concentration on the mechanical and morphological properties of cell-seeded fibrin hydrogels. Acta Biomater. 2007;3(1):59-67.

61. Blomback B, Okada M. Fibrin gel structure and clotting time. Thromb Res. 1982;25(1-2):51-70

62. Henderson SJ, Xia J, Wu H, Stafford AR, Leslie BA, Fredenburgh JC, et al. Zinc promotes clot stability by accelerating clot formation and modifying fibrin structure. Thromb Haemost. 2016;115(3):533-42.

63. Coffin ST, Gaudette GR. Aprotinin extends mechanical integrity time of cellseeded fibrin sutures. J Biomed Mater Res A. 2016;104(9):2271-9.

64. Park $\mathrm{CH}, \mathrm{Oh} \mathrm{J}-\mathrm{H}$, Jung H-M, Choi Y, Rahman SU, Kim S, et al. Effects of the incorporation of epsilon-aminocaproic acid/chitosan particles to fibrin on cementoblast differentiation and cementum regeneration. Acta Biomater. 2017;61:134-43.

65. Rosenfeld MA, Vasilyeva AD, Yurina LV, Bychkova AV. Oxidation of proteins: is it a programmed process? Free Radic Res. 2018;52(1):14-38.

66. Robinson M, Douglas S, Willerth SM. Mechanically stable fibrin scaffolds promote viability and induce neurite outgrowth in neural aggregates derived from human induced pluripotent stem cells. Sci Rep. 2017;7.

67. Willerth SM, Arendas KJ, Gottlieb DI, Sakiyama-Elbert SE. Optimization of fibrin scaffolds for differentiation of murine embryonic stem cells into neural lineage cells. Biomaterials. 2006;27(36):5990-6003.

68. Cholewinski E, Dietrich M, Flanagan TC, Schmitz-Rode T, Jockenhoevel S. Tranexamic acid-an alternative to Aprotinin in fibrin-based cardiovascular tissue engineering. Tissue Eng A. 2009;15(11):3645-53.

69. Robinson M, Valente KP, Willerth SM. A Novel Toolkit for Characterizing the Mechanical and Electrical Properties of Engineered Neural Tissues. Biosensors-Basel. 2019:9(2).

70. Christenson JT, Kalangos A. Autologous fibrin glue reinforced by platelets in surgery of ascending aorta. Thorac Cardiovasc Surg. 2004;52(4):225-9.

71. Kasemkijwattana C, Rungsinaporn V, Siripisitsak T, Kongmalai P, Boonprasert R, Charoenthamruksa C, et al. Autologous Fibrin-Base Scaffold for Chondrocytes and Bone Marrow Mesenchymal Stem Cells Implantation: The Development and Comparison to Conventional Fibrin Glue. J Med Assoc Thailand. 2016;99(Suppl 8):S99-S104.

72. Anitua E, Nurden P, Prado R, Nurden AT, Padilla S. Autologous fibrin scaffolds: when platelet- and plasma-derived biomolecules meet fibrin. Biomaterials. 2019;192:440-60.

73. Sharp KG, Dickson AR, Marchenko SA, Yee KM, Emery PN, Laidmåe I, et al. Salmon fibrin treatment of spinal cord injury promotes functional recovery and density of serotonergic innervation. Exp Neurol. 2012; 235(1):345-56.

74. Spejo AB, Chiarotto GB, Ferreira ADF, Gomes DA, Ferreira RS, Barraviera B, et al. Neuroprotection and immunomodulation following intraspinal axotomy of motoneurons by treatment with adult mesenchymal stem cells. J Neuroinflammation. 2018;15.

75. Araujo MR, Kyrylenko S, Spejo AB, Castro MV, Ferreira Junior RS, Barraviera B, et al. Transgenic human embryonic stem cells overexpressing FGF2 stimulate neuroprotection following spinal cord ventral root avulsion. Exp Neurol. 2017;294:45-57. 
76. de Castro MV, Barbizan R, Ferreira RS, Barraviera B, de Oliveira ALR. Direct spinal ventral root repair following avulsion: effectiveness of a new heterologous fibrin sealant on Motoneuron survival and regeneration. Neural Plast. 2016;2016:2932784. https://doi.org/10.1155/2016/2932784.

77. Francis NL, Hunger PM, Donius AE, Riblett BW, Zavaliangos A, Wegst UGK, et al. An ice-templated, linearly aligned chitosan-alginate scaffold for neural tissue engineering. J Biomed Mater Res A. 2013;101(12):3493-503.

78. Riblett BW, Francis NL, Wheatley MA, Wegst UGK. Ice-Templated scaffolds with microridged pores direct DRG Neurite growth. Adv Funct Mater. 2012; 22(23):4920-3.

79. Hyatt AJT, Wang D, van Oterendorp C, Fawcett JW, Martin KR. Mesenchymal stromal cells integrate and form longitudinally-aligned layers when delivered to injured spinal cord via a novel fibrin scaffold. Neurosci Lett. 2014:569:12-7

80. Yao $X$, Peng R, Ding J. Cell-material interactions revealed via material techniques of surface patterning. Adv Mater. 2013;25(37):5257-86.

81. Thannickal VJ, Lee DY, White ES, Cui Z, Larios JM, Chacon R, et al. Myofibroblast differentiation by transforming growth factor-beta 1 is dependent on cell adhesion and integrin signaling via focal adhesion kinase. J Biol Chem. 2003;278(14):12384-9.

82. Derynck R, Zhang YE. Smad-dependent and Smad-independent pathways in TGF-beta family signalling. Nature. 2003;425(6958):577-84.

83. Teo BKK, Wong ST, Lim CK, Kung TYS, Yap CH, Ramagopal Y, et al. Nanotopography modulates Mechanotransduction of stem cells and induces differentiation through focal adhesion kinase. ACS Nano. 2013;7(6):4785-98.

84. Weber M, de Torre IG, Moreira R, Frese J, Oedekoven C, Alonso M, et al. Multiple-step injection molding for fibrin-based tissue-engineered heart valves. Tissue Eng Part C-Methods. 2015;21(8):832-40.

85. Yao S, He F, Cao Z, Sun Z, Chen Y, Zhao H, et al. Mesenchymal stem cellladen hydrogel microfibers for promoting nerve Fiber regeneration in longdistance spinal cord transection injury. Acs Biomater Sci Eng. 2020;6(2): 1165-75.

86. Zhang Z, Yao S, Xie S, Wang X, Chang F, Luo J, et al. Effect of hierarchically aligned fibrin hydrogel in regeneration of spinal cord injury demonstrated by tractography: a pilot study. Sci Rep. 2017;7.

87. de la Vega L, Rosas Gomez DA, Abelseth E, Abelseth L, da Silva VA, Willerth SM. 3D Bioprinting Human Induced Pluripotent Stem Cell-Derived Neural Tissues Using a Novel Lab-on-a-Printer Technology. Applied Sciences-Basel. 2018;8(12).

88. Sander EA, Barocas VH, Tranquillo RT. Initial Fiber alignment pattern alters extracellular matrix synthesis in fibroblast-populated fibrin gel Cruciforms and correlates with predicted tension. Ann Biomed Eng. 2011;39(2):714-29.

89. Chen CM, Tang JC, Gu Y, Liu LL, Liu XZ, Deng LF, et al. Bioinspired Hydrogel Electrospun Fibers for Spinal Cord Regeneration. Advanced Functional Materials. 2019;29(4)

90. Koffler J, Zhu W, Qu X, Platoshyn O, Dulin JN, Brock J, et al. Biomimetic 3Dprinted scaffolds for spinal cord injury repair. Nat Med. 2019;25(2):263.

91. Fuhrmann T, Tam RY, Ballarin B, Coles B, Donaghue IE, van der Kooy D, et al. Injectable hydrogel promotes early survival of induced pluripotent stem cell-derived oligodendrocytes and attenuates longterm teratoma formation in a spinal cord injury model. Biomaterials. 2016;83:23-36.

92. Rose JC, Gehlen DB, Kohler THJ, Licht CJ, De Laporte L. Biofunctionalized aligned microgels provide 3D cell guidance to mimic complex tissue matrices. Biomaterials. 2018;163:128-41.

93. Omidinia-Anarkoli A, Boesveld S, Tuvshindorj U, Rose JC, Haraszti T, De Laporte L. An Injectable Hybrid Hydrogel with Oriented Short Fibers Induces Unidirectional Growth of Functional Nerve Cells. Small. 2017;13(36).

94. Johnson CDL, Ganguly D, Zuidema JM, Cardina TJ, Ziemba AM, Kearns KR, et al. Injectable, magnetically orienting electrospun Fiber conduits for neuron guidance. ACS Appl Mater Interfaces. 2019;11(1):356-72.

95. Kim MS, Ahn HH, Shin YN, Cho MH, Khang G, Lee HB. An in vivo study of the host tissue response to subcutaneous implantation of PLGA- and/or porcine small intestinal submucosa-based scaffolds. Biomaterials. 2007; 28(34):5137-43.

96. Oh TH, Markelonis GJ, Von Visger JR, Baik B, Shipley MT. Acidic pH rapidly increases immunoreactivity of glial fibrillary acidic protein in cultured astrocytes. Glia. 1995;13(4):319-22.

97. Fu K, Pack DW, Klibanov AM, Langer R. Visual evidence of acidic environment within degrading poly (lactic-co-glycolic acid) (PLGA) microspheres. Pharm Res. 2000;17(1):100-6.
98. Liu G, Gao J, Ai H, Chen X. Applications and potential toxicity of magnetic Iron oxide nanoparticles. Small. 2013;9(9-10):1533-45.

99. Gessmann J, Seybold D, Peter E, Schildhauer TA, Koeller M. Alignment of the fibrin network within an autologous plasma clot. Tissue Eng Part CMethods. 2016;22(1):30-7.

100. Berkovitch Y, Cohen T, Peled E, Schmidhammer R, Florian H, Teuschl AH, et al. Hydrogel composition and laser micropatterning to regulate sciatic nerve regeneration. J Tissue Eng Regen Med. 2018;12(4):1049-61.

101. Assinck P, Duncan GJ, Hilton BJ, Plemel JR, Tetzlaff W. Cell transplantation therapy for spinal cord injury. Nat Neurosci. 2017;20(5):637-47.

102. Mukhamedshina YO, Akhmetzyanova ER, Kostennikov AA, Zakirova EY, Galieva LR, Garanina EE, et al. Adipose-derived Mesenchymal stem cell application combined with fibrin matrix promotes structural and functional recovery following spinal cord injury in rats. Front Pharmacol. 2018;9.

103. De Berdt P, Bottemanne P, Bianco J, Alhouayek M, Diogenes A, Llyod A, et al. Stem cells from human apical papilla decrease neuro-inflammation and stimulate oligodendrocyte progenitor differentiation via activin-a secretion. Cell Mol Life Sci. 2018;75(15):2843-56.

104. Cruz-Martinez P, Gonzalez-Granero S, Molina-Navarro MM, Pacheco-Torres J, Garcia-Verdugo JM, Geijo-Barrientos E, et al. Intraventricular injections of mesenchymal stem cells activate endogenous functional remyelination in a chronic demyelinating murine model. Cell Death Dis. 2016;7.

105. Chung H-j, Chung W-h, Lee J-H, Chung D-J, Yang W-J, Lee AJ, et al. Expression of neurotrophic factors in injured spinal cord after transplantation of human-umbilical cord blood stem cells in rats. J Vet Sci. 2016;17(1):97-102.

106. Li J, Li N, Jiang Y. Mesenchymal stem cells secrete brain-derived Neurotrophic factor and promote retinal ganglion cell survival after traumatic optic neuropathy. J Craniofac Surg. 2015;26(2):548-52.

107. Hsu R-S, Chen P-Y, Fang J-H, Chen Y-Y, Chang C-W, Lu Y-J, et al. Adaptable Microporous Hydrogels of Propagating NGF-Gradient by Injectable Building Blocks for Accelerated Axonal Outgrowth. Advanced Science. 2019;6(16).

108. Petrou P, Gothelf Y, Argov Z, Gotkine M, Levy YS, Kassis I, et al. Safety and clinical effects of Mesenchymal stem cells secreting Neurotrophic factor transplantation in patients with amyotrophic lateral sclerosis results of phase 1/2 and 2a clinical trials. JAMA Neurol. 2016;73(3):337-44.

109. Gao F, Chiu SM, Motan DAL, Zhang Z, Chen L, Ji HL, et al. Mesenchymal stem cells and immunomodulation: current status and future prospects. Cell Death Dis. 2016;7

110. Wang Q, Sun G, Gao C, Feng L, Zhang Y, Hao J, et al. Bone marrow mesenchymal stem cells attenuate 2,5-hexanedione-induced neuronal apoptosis through a NGF/AKT-dependent pathway. Sci Rep. 2016;6.

111. Chen Q, Zhang Z, Liu J, He Q, Zhou Y, Shao G, et al. A fibrin matrix promotes the differentiation of EMSCs isolated from nasal respiratory mucosa to Myelinating Phenotypical Schwann-like cells. Mol Cells. 2015; 38(3):221-8.

112. Kjell J, Olson L. Rat models of spinal cord injury: from pathology to potential therapies. Dis Model Mech. 2016;9(10):1125-37.

113. Luzzi S, Crovace AM, Lacitignola L, Valentini V, Francioso E, Rossi G, et al. Engraftment, neuroglial transdifferentiation and behavioral recovery after complete spinal cord transection in rats. Surg Neurol Int. 2018;9:19.

114. Ibarra A, Mendieta-Arbesu E, Suarez-Meade P, Garcia-Vences E, Martinon S, Rodriguez-Barrera R, et al. Motor recovery after chronic spinal cord transection in rats: a proof-of-concept study evaluating a combined strategy. Cns Neurol Disord -Drug Targets. 2019;18(1):52-62.

115. Mukhamedshina Y, Shulman I, Ogurcov S, Kostennikov A, Zakirova E, Akhmetzyanova E, et al. Mesenchymal Stem Cell Therapy for Spinal Cord Contusion: A Comparative Study on Small and Large Animal Models. Biomolecules. 2019;9(12).

116. Zou Y, Zhao Y, Xiao Z, Chen B, Ma D, Shen H, et al. Comparison of regenerative effects of transplanting three-dimensional longitudinal scaffold loaded-human Mesenchymal stem cells and human neural stem cells on spinal cord completely transected rats. Acs Biomater Sci Eng. 2020;6(3):1671-80.

117. Silva J, Bento AR, Barros D, Laundos TL, Sousa SR, Quelhas P, et al. Fibrin functionalization with synthetic adhesive ligands interacting with alpha 6 beta 1 integrin receptor enhance neurite outgrowth of embryonic stem cell-derived neural stem/progenitors. Acta Biomater. 2017:59:243-56.

118. Robinson J, Lu P. Optimization of trophic support for neural stem cell grafts in sites of spinal cord injury. Exp Neurol. 2017;291:87-97. 
119. Wilems TS, Pardieck J, lyer N, Sakiyama-Elbert SE. Combination therapy of stem cell derived neural progenitors and drug delivery of anti-inhibitory molecules for spinal cord injury. Acta Biomater. 2015;28:23-32.

120. Bento AR, Quelhas P, Oliveira MJ, Pego AP, Amaral IF. Three-dimensional culture of single embryonic stem-derived neural/stem progenitor cells in fibrin hydrogels: neuronal network formation and matrix remodelling. J Tissue Eng Regen Med. 2017;11(12):3494-507.

121. Monfared MJ, Nasirinezhad F, Ebrahimi-Barough S, Hasanzade G, Saberi H, Tavangar SM, et al. Transplantation of miR-219 overexpressed human endometrial stem cells encapsulated in fibrin hydrogel in spinal cord injury. J Cell Physiol. 2019;234(10):18887-96.

122. Jessen KR, Mirsky R. The repair Schwann cell and its function in regenerating nerves. J Physiol -London. 2016:594(13):3521-31.

123. Hoben G, Yan Y, lyer N, Newton P, Hunter DA, Moore AM, et al. Comparison of acellular nerve allograft modification with Schwann cells or VEGF. Hand (New York). 2015;10(3):396-402

124. Rodriguez FJ, Verdu E, Ceballos D, Navarro X. Nerve guides seeded with autologous Schwann cells improve nerve regeneration. Exp Neurol. 2000; 161(2):571-84

125. Masgutov R, Masgutova G, Mullakhmetova A, Zhuravleva M, Shulman A, Rogozhin A, et al. Adipose-derived Mesenchymal stem cells applied in fibrin glue stimulate peripheral nerve regeneration. Front Med. 2019;6.

126. Hurtado A, Moon LDF, Maquet V, Blits B, Jerome R, Oudega M. Poly ( $D, L-$ lactic acid) macroporous guidance scaffolds seeded with Schwann cells genetically modified to secrete a bi-functional neurotrophin implanted in the completely transected adult rat thoracic spinal cord. Biomaterials. 2006; 27(3):430-42.

127. Meijs MFL, Timmers L, Pearse DD, Tresco PA, Bates ML, Joosten EAJ, et al. Basic fibroblast growth factor promotes neuronal survival but not behavioral recovery in the transected and Schwann cell implanted rat thoracic spinal cord. J Neurotrauma. 2004;21(10):1415-30.

128. Ganz J, Shor E, Guo S, Sheinin A, Arie I, Michaelevski I, et al. Implantation of 3D constructs embedded with Oral mucosa-derived cells induces functional recovery in rats with complete spinal cord transection. Front Neurosci. 2017;11.

129. Jose A, Krishnan LK. Effect of matrix composition on differentiation of nestin-positive neural progenitors from circulation into neurons. Journal of Neural Engineering. 2010;7(3).

130. Barbizan R, Castro MV, Barraviera B, Ferreira RS, Jr., Oliveira ALR. Influence of Delivery Method on Neuroprotection by Bone Marrow Mononuclear Cell Therapy following Ventral Root Reimplantation with Fibrin Sealant. Plos One. 2014;9(8)

131. Barbizan R, Castro MV, Ferreira RS Jr, Barraviera B, Oliveira ALR. Long-term spinal ventral root Reimplantation, but not bone marrow mononuclear cell treatment, positively influences Ultrastructural synapse recovery and motor axonal regrowth. Int J Mol Sci. 2014;15(11):19535-51.

132. Benitez SU, Barbizan R, Spejo AB, Ferreira RS, Barraviera B, Goes AM, et al. Synaptic plasticity and sensory-motor improvennent following fibrin sealant dorsal root reimplantation and mononuclear cell therapy. Front Neuroanat. 2014:8.

133. Kojima K, Miyoshi H, Nagoshi N, Kohyama J, Itakura G, Kawabata S, et al. Selective ablation of tumorigenic cells following human induced pluripotent stem cell-derived neural stem/progenitor cell transplantation in spinal cord injury. Stem Cells Transl Med. 2019:8(3):260-70.

134. Farina M, Alexander JF, Thekkedath U, Ferrari M, Grattoni A. Cell encapsulation: overcoming barriers in cell transplantation in diabetes and beyond. Adv Drug Deliv Rev. 2019;139:92-115.

135. Johnson PJ, Tatara A, McCreedy DA, Shiu A, Sakiyama-Elbert SE. Tissueengineered fibrin scaffolds containing neural progenitors enhance functional recovery in a subacute model of SCI. Soft Matter. 2010;6(20): 5127-37.

136. Ma T, Zhu L, Yang Y, Quan X, Huang L, Liu Z, et al. Enhanced in vivo survival of Schwann cells by a synthetic oxygen carrier promotes sciatic nerve regeneration and functional recovery. J Tissue Eng Regen Med. 2018; 12(1):E177-E89.

137. Arulmoli J, Wright HJ, Phan DTT, Sheth U, Que RA, Botten GA, et al. Combination scaffolds of salmon fibrin, hyaluronic acid, and laminin for human neural stem cell and vascular tissue engineering. Acta Biomater. 2016:43:122-38

138. Tatic N, Rose F, des Rieux A, White LJ. Stem cells from the dental apical papilla in extracellular matrix hydrogels mitigate inflammation of microglial cells. Scientific Reports. 2019;9.
139. Edgar JM, Robinson M, Willerth SM. Fibrin hydrogels induce mixed dorsal/ ventral spinal neuron identities during differentiation of human induced pluripotent stem cells. Acta Biomater. 2017;51:237-45.

140. Nazari B, Kazemi M, Kamyab A, Nazari B, Ebrahimi-Barough S, Hadjighassem $M$, et al. Fibrin hydrogel as a scaffold for differentiation of induced pluripotent stem cells into oligodendrocytes. J Biomed Mater Res Part BAppl Biomater. 2020;108(1):192-200.

141. Pajer K, Bellak T, Red H, Nogradi A. Neuroectodermal stem cells grafted into the injured spinal cord induce both axonal regeneration and morphological restoration via multiple mechanisms. J Neurotrauma. 2019;36(21):2977-90.

142. Liu C, Fan L, Xing J, Wang Q, Lin C, Liu C, et al. Inhibition of astrocytic differentiation of transplanted neural stem cells by chondroitin sulfate methacrylate hydrogels for the repair of injured spinal cord. Biomater Sci. 2019;7(5):1995-2008.

143. Lu P, Wang Y, Graham L, McHale K, Gao M, Wu D, et al. Long-distance growth and connectivity of neural stem cells after severe spinal cord injury. Cell. 2012;150(6):1264-73.

144. Steward O, Sharp KG, Yee KM, Hatch MN, Bonner JF. Characterization of ectopic colonies that form in widespread areas of the nervous system with neural stem cell transplants into the site of a severe spinal cord injury. J Neurosci. 2014;34(42):14013-21.

145. Johnson PJ, Tatara A, Shiu A, Sakiyama-Elbert SE. Controlled release of Neurotrophin-3 and platelet-derived growth factor from fibrin scaffolds containing neural progenitor cells enhances survival and differentiation into neurons in a subacute model of SCI. Cell Transplant. 2010;19(1):89-101.

146. Ko C-C, Tu T-H, Wu J-C, Huang W-C, Tsai Y-A, Huang S-F, et al. Functional improvement in chronic human spinal cord injury: four years after acidic fibroblast growth factor. Sci Rep. 2018;8.

147. Wu JC, Huang WC, Chen YC, Tu TH, Tsai YA, Huang SF, et al. Acidic fibroblast growth factor for repair of human spinal cord injury: a clinical trial. J Neurosurg Spine. 2011;15(3):216-27.

148. Chiu C-W, Huang W-H, Kuo H-S, Tsai M-J, Chen C-J, Lee M-J, et al. Local inhibition of matrix metalloproteinases reduced $\mathrm{M} 2$ macrophage activity and impeded recovery in spinal cord transected rats after treatment with fibroblast growth factor-1 and nerve grafts. Neural Regen Res. 2018;13(8): 1447-54.

149. Lee YB, Polio S, Lee W, Dai GH, Menon L, Carroll RS, et al. Bio-printing of collagen and VEGF-releasing fibrin gel scaffolds for neural stem cell culture. Exp Neurol. 2010;223(2):645-52.

150. Loureiro J, Torres AL, Neto T, Aguiar P, Barrias CC, Pinto MT, et al. Conjugation of the T1 sequence from CCN1 to fibrin hydrogels for therapeutic vascularization. Mater Sci Eng C-Materi Biol Appl. 2019;104.

151. Sundem L, Tseng K-CC, Li H, Ketz J, Noble M, Elfar J. Erythropoietin enhanced recovery after traumatic nerve injury: myelination and localized effects. J Hand Surg Am. 2016;41(10):999-1010.

152. Moreno PMD, Ferreira AR, Salvador D, Rodrigues MT, Torrado M, Carvalho ED, et al. Hydrogel-assisted antisense LNA Gapmer delivery for in situ gene silencing in spinal cord injury. Mol Ther Nucleic Acids. 2018;11:393-406.

153. Kang-Mieler JJ, Dosmar E, Liu W, Mieler WF. Extended ocular drug delivery systems for the anterior and posterior segments: biomaterial options and applications. Expert Opin Drug Deliv. 2017;14(5):611-20.

154. Taylor SJ, McDonald JW, Sakiyama-Elbert SE. Controlled release of neurotrophin-3 from fibrin gels for spinal cord injury. J Control Release. 2004:98(2):281-94.

155. Hyatt AJT, Wang D, Kwok JC, Fawcett JW, Martin KR. Controlled release of chondroitinase $A B C$ from fibrin gel reduces the level of inhibitory glycosaminoglycan chains in lesioned spinal cord. J Control Release. 2010; 147(1):24-9.

156. Wilems TS, Sakiyama-Elbert SE. Sustained dual drug delivery of antiinhibitory molecules for treatment of spinal cord injury. J Control Release. 2015:213:103-11.

157. Bracken MB. Steroids for acute spinal cord injury. Cochrane Database Syst Rev. 2012;1.

158. Karabey-Akyurek Y, Gurcay AG, Gurcan O, Turkoglu OF, Yabanoglu-Ciftci S, Eroglu $\mathrm{H}$, et al. Localized delivery of methylprednisolone sodium succinate with polymeric nanoparticles in experimental injured spinal cord model. Pharm Dev Technol. 2017;22(8):972-81.

159. Tajdaran K, Chan K, Shoichet MS, Gordon T, Borschel GH. Local delivery of FK506 to injured peripheral nerve enhances axon regeneration after surgical nerve repair in rats. Acta Biomater. 2019;96:211-21.

160. Panayi AC, Orgill DP. Current use of biological scaffolds in plastic surgery. Plast Reconstr Surg. 2019;143(1):209E-20E. 
161. Lu LC, Arbit HM, Herrick JL, Segovis SG, Maran A, Yaszemski MJ. Tissue engineered constructs: perspectives on clinical translation. Ann Biomed Eng. 2015;43(3):796-804.

162. Straley KS, Foo CWP, Heilshorn SC. Biomaterial design strategies for the treatment of spinal cord injuries. J Neurotrauma. 2010;27(1):1-19.

\section{Publisher's Note}

Springer Nature remains neutral with regard to jurisdictional claims in published maps and institutional affiliations.

Ready to submit your research? Choose BMC and benefit from:

- fast, convenient online submission

- thorough peer review by experienced researchers in your field

- rapid publication on acceptance

- support for research data, including large and complex data types

- gold Open Access which fosters wider collaboration and increased citations

- maximum visibility for your research: over $100 \mathrm{M}$ website views per year

At $B M C$, research is always in progress.

Learn more biomedcentral.com/submissions 